\title{
EVALUASI PERFORMA USABILITY SITUS-SITUS WEB PERGURUAN TINGGI NEGERI DI INDONESIA YANG TERAKREDITASI “A” TAHUN 2013 SERTA PERBANDINGAN KONDISI SITUS WEB TAHUN 2014 DAN 2017
}

\author{
Yuditha Ichsani \\ Program Studi Teknik Informatika, Fakultas Sains dan Teknologi \\ Universitas Islam Negeri Syarif Hidayatullah Jakarta \\ yuditha.ichsani@uinjkt.ac.id
}

\begin{abstract}
ABSTRAK
Artikel ini berisi tentang hasil evaluasi usability terhadap situs web Perguruan Tinggi Negeri (PTN) di Indonesia yang memperoleh Akreditasi A dari Badan Akreditasi Nasional Perguruan Tinggi (BAN-PT) pada tahun 2013 yang masih berlaku hingga tahun 2017. Adapun berdasarkan hasil penelitian, PTN yang memperoleh skor kepuasan pengguna tertinggi dalam hal situs web adalah Universitas Gajah Mada. Adapun Perguruan Tinggi yang memiliki skor kepuasan pengguna terendah adalah Universitas Diponegoro. Berdasarkan hasil uji korelasi antara hasil rata-rata QUIS dan rata-rata level permasalahan usability, dapat disimpulkan bahwa keduanya memiliki korelasi yang kuat, nyata dan searah $(\mathrm{r}=0.21, \mathrm{p}=$ 0.000). Dengan kata lain, jika hasil rata-rata QUIS semakin tinggi, maka dapat diasumsikan kondisi permasalahan usability situs web tersebut semakin rendah. Situs web UNHAS memiliki performa usability tertinggi dengan skor terkecil berdasarkan hasil normalisasi (5.8205), sedangkan situs web UNDIP memiliki performa usability terendah dengan skor terbesar (23.4430). Perubahan situs web UIN Jakarta pada tahun 2017 jika dibandingkan dengan tahun 2014 ialah ditambahkannya breadcrumps navigation, fitur drop-down pada menu bar, dan mesin pencari. Sementara pada situs web UI tahun 2017 telah ditambahkan 7 mепи bar dari yang semula hanya 5 menu bar, kemudian pada situs web UNDIP telah menggunakan menu bar di bagian atas (header) setelah sebelumnya hanya menggunakan tautan dan ditambahkan pula alamat surat elektronik dan tautan-tautan kepada media sosial UNDIP.
\end{abstract}

Kata Kunci: usability, performa, webometrics, situs web, perguruan tinggi

\begin{abstract}
This article contains of website usability evaluation result of the State Universities in Indonesia to obtain accreditation from the National Accreditation Board of Higher Education in 2013 which is still valid until 2017. The basis of research, universities that received the highest user satisfaction scores in terms of website is Gadjah Mada University. The university that have the lowest user satisfaction score is Diponegoro University. Based on the results of correlation between the average QUIS yield and average usability problems level, it can be concluded that both have a strong correlation, real and direction $(\mathrm{r}=$ 0621, $\mathrm{p}=0.000$ ). In other words, if the average QUIS score is higher, then it can be predicted conditions that website usability problems getting lower. UNHAS website has the highest usability performance with the smallest score is based on the results of normalization (5.8205), while UNDIP website has the lowest usability performance with the largest score (23.4430). Changes of UIN Jakarta website in 2017 compared to 2014 are adding breadcrumps navigation, a drop-down menu feature on the menu bar, and search engine. While on the UI website 2017 has added 7 menu bars from the only 5 menu bars originally, then on UNDIP website has used the menu bar at the top position (header) after previously only use the links and also added the email address and links to UNDIP social medias.
\end{abstract}

Keywords: usability, performance, webometrics, website, university

DOI: $10.15408 /$ jti.v10i2.6824

Yuditha Ichsani : Evaluasi Performa Usability... 93-108

p-ISSN 1979-9160 | e-ISSN 2549-7901 


\section{PENDAHULUAN}

Produk teknologi informasi seperti situs web dalam menyajikan berbagai kebutuhan informasi dan layanan digital bagi pengguna telah semakin beragam, kreatif dan inovatif. Namun pada kenyataannya saat ini, belum semua situs web telah memenuhi prinsip-prinsip dasar seperti mudah diakses (accessible) dan mudah digunakan (usable). Salah satu cara untuk dapat mengetahui seberapa jauh situs web mudah digunakan adalah dengan usability testing, yakni "memperhatikan orang-orang yang mencoba menggunakan apa yang Anda ciptakan, desain, atau bangun dengan tujuan untuk membuatnya lebih mudah digunakan oleh orang lain atau membuktikan bahwa ciptaan Anda tersebut mudah digunakan" [1].

Menurut [2], desain yang berpusat pada pengguna (User-Centered Design atau UCD) adalah prinsip dasar untuk menciptakan sistem dan perangkat yang dapat digunakan (usable). Salah satu alasan yang paling umum adalah bahwa perancang dan pengembang perlu mencocokkan waktu yang tepat. Pada intinya UCD adalah proses yang mengandalkan pemahaman sistematis terhadap pengguna (user) dan lingkungan mereka, serta proses desain dan pengujian yang berulang-ulang berdasarkan pada tujuan kinerja pengguna.

Dewasa ini, Perguruan Tinggi (PT) dituntut untuk memperhatikan dan mengelola arus informasi yang mengalir di dalam dan dari luar lingkungannya dengan penerapan dan pemanfaatan TIK walaupun secara prinsip, eksistensi PT tidak tergantung kepada TIK, namun teknologi tersebut secara langsung memberikan keunggulan kompetitif (competitive advantage) kepada PT yang berhasil menggunakannya secara optimal. Salah satu sarana pada PT yang tergolong ke dalam pemanfaatan TIK secara optimal adalah situs web. Setiap PT yang peduli terhadap kredibilitas, eksistensi dan integritasnya baik secara nasional maupun internasional, sudah selayaknya memiliki situs web yang dapat diakses oleh siapapun, kapanpun dan dimanapun. Untuk dapat mewujudkan situs web yang user-friendly, diperlukan evaluasi terhadap situs web PT dalam hal berbagai macam performa antarmuka pengguna, seperti usability.
Untuk meraih status sebagai World Class University (WCU) adalah impian bagi banyak Institusi Pendidikan Tinggi. Dalam mewujudkan impian ini, Institusi Pendidikan Tinggi harus memenuhi acuan yang mendasari penentuan peringkat WCU ini. Salah satu barometer yang dapat digunakan adalah Webometrics Ranking of World University (WRWU). Webometrics menampilkan beberapa kesamaan informetric dan studi scientometric dan penerapan metode bibliometrik umum. Misalnya, jumlah sederhana dan analisis isi dari halaman web seperti analisis publikasi tradisional; hitungan dan analisis dari link keluar dari halaman web, di sini bernama outlinks, dan link yang menunjuk ke halaman web, yang disebut inlinks, dapat dilihat masing-masing sebagai referensi dan kutipan analisis [3].

Pada rilis peringkat Webometrics bulan Januari tahun 2011 saja, di Indonesia ada 5 Perguruan Tinggi yang masuk ke dalam 1000 universitas terbaik dunia. Total ada 143 Perguruan Tinggi di Indonesia yang masuk ke dalam 5000 universitas terbaik. Tentunya, diperlukan strategi dan manajemen pengelolaan situs web yang baik untuk dapat meraih peringkat atas dalam daftar Webometrics Ranking of World University (WRWU).

Berdasarkan latar belakang di atas, topik yang diambil pada penelitian ini ialah mengenai evaluasi usability terhadap situs web Perguruan Tinggi negeri (PTN) di Indonesia yang memperoleh Akreditasi A dari Badan Akreditasi Nasional Perguruan Tinggi (BAN-PT) pada tahun 2013 berdasarkan data paling akhir yang ditampilkan pada situs web dan masih bertahan peringkatnya hingga paper ini dibuat (tahun 2017), yaitu Institut Teknologi Bandung atau ITB, Institut Pertanian Bogor atau IPB, Universitas Gadjah Mada atau UGM, Universitas Indonesia atau UI, Universitas Diponegoro atau UNDIP, Universitas Hasanuddin atau UNHAS, dan Universitas Islam Negeri (UIN) Syarif Hidayatullah Jakarta. Adapun nomor SK beserta tanggal kedaluwarsanya disajikan pada Tabel 1. 
Tabel 1. Nomor SK 7 Perguruan Tinggi Negeri [4]

\begin{tabular}{|c|c|c|c|}
\hline No & Nama PTN & Nomor SK & $\begin{array}{c}\text { Tanggal } \\
\text { Kedaluwarsa }\end{array}$ \\
\hline 1 & ITB & 066/SK/BAN-PT/Ak-IV/PT/II/2013 & 21 Pebruari 2018 \\
\hline 2 & IPB & 067/SK/BAN-PT/Ak-IV/PT/II/2013 & 21 Pebruari 2018 \\
\hline 3 & UGM & 068/SK/BAN-PT/Ak-IV/PT/II/2013 & 21 Pebruari 2018 \\
\hline 4 & UI & 069/SK/BAN-PT/Ak-IV/PT/II/2013 & 21 Pebruari 2018 \\
\hline 5 & UNHAS & 079/SK/BAN-PT/Ak-IV/PT/II/2013 & 21 Pebruari 2018 \\
\hline 6 & UNDIP & 125/SK/BAN-PT/Ak-SURV/PT/V/2013 & 24 Mei 2018 \\
\hline 7 & UIN Syarif Hidayatullah Jakarta & 126/SK/BAN-PT/Ak-SURV/PT/V/2013 & 24 Mei 2018 \\
\hline
\end{tabular}

Adapun metode yang digunakan pada evaluasi usability adalah observasi pengguna yang mengakses suatu sistem atau situs web secara langsung berdasarkan pada metode [5] dimana metode tersebut dianggap lebih objektif dan efektif daripada hanya melakukan suatu demonstrasi sistem atau situs web dan meminta umpan balik dari pengguna secara subjektif. Selain itu, pada paper juga dilakukan perbandingan antara situs web UIN Jakarta pada tahun 2014 dengan tahun 2017 sebagai contoh kasusnya.

\section{STUDI LITERATUR}

\subsection{Usability}

Terdapat beberapa definisi mengenai usability. Definsi pertama disampaikan oleh International Standards Organization (ISO 9241-11) yang mendefinisikan usability sebagai "sejauh mana suatu produk dapat digunakan oleh pengguna tertentu untuk memperoleh tujuan tertentu dengan efektifitas, efisiensi, dan kepuasan dalam konteks penggunaan."'

Selanjutnya Usability Professionals Association (UPA), memberikan definisi usability yang lebih berfokus kepada proses pengembangan produk, yaitu "Usability adalah suatu pendekatan terhadap pengembangan produk yang menggabungkan umpan balik pengguna melalui siklus pengembangan untuk mengurangi biaya dan menciptakan produk dan alat yang memenuhi kebutuhan pengguna." Definisi berikutnya ialah "Usability berarti memastikan bahwa sesuatu bekerja dengan baik untuk tujuan tertentu tanpa penggunanya menjadi putus asa', [6].

Berbagai macam definisi usability tersebut memiliki tiga tema yang serupa, yaitu adanya keterlibatan seorang pengguna,

Yuditha Ichsani : Evaluasi Performa Usability... 93-108 pengguna melakukan suatu pekerjaan, dan pengguna melakukan sesuatu dengan adanya produk, sistem atau hal lain [6].

\subsection{Evaluasi Usability}

Usability pada umumnya diukur dengan melibatkan sejumlah pengguna yang dipilih sebagai perwakilan dari pengguna sesungguhnya. Pengguna tersebut akan menggunakan sistem untuk menyelenggarakan serangkaian tugas khusus, meskipun sistem tersebut juga dapat diukur dengan melibatkan pengguna sesungguhnya di lapangan untuk melakukan tugas apapun yang memang sedang mereka lakukan [2].

Pada kasus tersebut poin pentingnya adalah bahwa usability dievaluasi relatif hanya pada pengguna tertentu dan tugas tertentu. Hal ini juga menjadi perhatian tertentu di mana sistem yang sama dapat diukur sebagai sistem dengan karakteristik usability yang berbeda jika digunakan oleh pengguna yang berbeda untuk tugas yang berbeda pula.

Terdapat tiga cara potensial untuk mengukur usability suatu produk, antara lain [7]:

1. Dengan menganalisis produk dalam konteks penggunaan: Usability dapat diukur dengan menilai fitur-fitur produk yang dibutuhkan untuk usability dalam konteks tertentu.

2. Dengan menganalisis proses interaksi: Usability dapat diukur dengan memodelkan interaksi antara seorang pengguna yang melaksanakan tugas dengan suatu produk.

3. Dengan menganalisis efektivitas dan efisiensi yang dihasilkan dari penggunaan produk dalam konteks tertentu dan mengukur kepuasan pengguna produk. Dikarenakan ini adalah pengukuran langsung terhadap usability, hal tersebut merupakan ujian akhir dari usability. Jika suatu produk lebih usable 
dalam suatu konteks tertentu, maka pengukuran usability akan lebih baik.

\subsection{Kualitas Situs Web}

Kualitas adalah kondisi dinamis yang berhubungan dengan produk, jasa, manusia, proses, dan lingkungan yang memenuhi atau melebihi harapan. Kesenjangan antara harapan dan kenyataan yang dirasakan akan menjadi perhatian orang dalam menilai suatu kualitas. Semakin kecil kesenjangan tersebut, maka akan semakin tinggi kualitasnya [8].

Kualitas ini meliputi berbagai hal yang terkait dalam penggunaan situ web. DeLone dan Mclean mengemukakan beberapa dimensi yang terkait dengan kualitas situs web, yaitu:

1. Kualitas Sistem (System Quality), pada lingkungan Internet environment, dimensi ini mengukur beberapa karakteristik yang diinginkan pada suatu sistem, contohnya sistem e-commerce. Usability, availability, reliability, adaptability, dan waktu respon (contohnya waktu untuk mengunduh) adalah contoh-contoh kualitas yang dinilai oleh pengguna sistem.

2. Kualitas Informasi (Information Quality), dimensi ini membahas masalah konten sistem. Konten situs web selayaknya bersifat personal, lengkap, relevan, mudah dipahami, dan aman.

3. Kualitas Layanan (Service Quality), keseluruhan dukungan yang disampaikan oleh penyedia layanan, berlaku terlepas dari apakah dukungan ini disampaikan oleh departemen IS, unit organisasi baru, atau penyedia jasa layanan Internet (Internet Service Provider) [9].

\subsection{Kepuasan Pengguna Situs Web}

Kepuasan dalam menggunakan suatu produk atau jasa adalah konsep penting. Oleh karena itu hal ini menjadi perhatian dari banyak pakar. Untuk mengukur kepuasan pengakses situs web selama melakukan penjelajahan, ialah seberapa jauh pengakses tersebut memiliki pengalaman yang menyenangkan pada saat mengakses situs web. Kualitas dan fitur situs web tentunya disediakan agar para pengguna memperoleh manfaat dan kepuasan dalam menggunakan situs web. Fitur merupakan fungsi-fungsi yang disediakan untuk membantu pengakses dalam menjelajahi situs web. Pengguna yang puas cenderung akan tetap menggunakan, sedangkan pengguna yang tidak puas akan memiliki alasan untuk meninggalkannya. Kepuasan yang tinggi tentunya akan menyebabkan tingkat penggunaan situs web menjadi tinggi karena pengguna tetap akan menggunakannya pada waktu mendatang [8].

\section{METODOLOGI}

Proses pengambilan data berupa observasi terhadap para responden merupakan proses utama dalam penelitian ini. Pengambilan data pada penelitian ini mengambil lokasi di salah satu ruangan di lantai 6 Gedung Pusat Laboratorium Terpadu - Fakultas Sains dan Teknologi, UIN Syarif Hidayatullah Jakarta dan dilakukan sejak tanggal 25 Agustus 2014 hingga 20 Oktober 2014. Adapun keseluruhan penelitian ini dilaksanakan pada bulan Juni 2014 sampai dengan bulan Desember 2014 sampai dengan tahap pelaporan.

Perangkat lunak yang digunakan pada penelitian ini ialah Camtasia Studio versi 8.1 sebagai perangkat lunak perekam layar (screen capture software), Google Chrome sebagai penjelajah Internet (Internet Browser), IBM SPSS Statistics 22 sebagai alat penguji korelasi dan Microsoft Office 2013 (Microsoft Word, Excel dan Powerpoint) untuk melakukan penulisan laporan, mengolah data dan mempresentasikan hasil penelitian.

Adapun perangkat keras yang digunakan antara lain komputer jinjing (laptop) bersistem operasi Windows 7 Home Basic 64-bits dan menggunakan prosesor Intel Celeron $1.50 \mathrm{GHz}$ yang dilengkapi dengan headset dan mikrofon untuk merekam suara responden, serta mouse dan mousepad untuk mempermudah mengakses situs web. Selain itu, komputer jinjing tersebut dilengkapi dengan koneksi modem langganan berbayar merek Huawei Bolt 4G sebagai penyedia jaringan Internet, dan satu set formulir kuesioner untuk pengumpulan data.

Penelitian ini menggunakan metode evaluasi usability dengan cara melakukan observasi dan uji kepuasan pengguna (user satisfaction test) secara langsung kepada beberapa orang responden [10]. Beberapa 
tahapan pelaksanaan evaluasi usability dijelaskan pada beberapa bagian di bawah ini:

a. Penentuan jenis dan jumlah pengguna yang bertindak sebagai responden evaluasi usability

b. Perancangan skenario penyelesaian tugas.

1) Sejarah Perguruan Tinggi

2) Visi dan Misi

3) Publikasi Ilmiah [11]

4) Informasi Akademik [11]

5) Informasi Beasiswa [12]

6) Informasi Peluang Kerja [12]

7) Berita atau Artikel Terbaru

8) Buku Tamu

9) Mesin Pencari Informasi

c. Pilot Test

d. Perancangan kuesioner evaluasi usability dan kepuasan pengguna

e. Pelaksanaan proses evaluasi usability

f. Menetapkan skor performa evaluasi usability untuk setiap situs web Perguruan Tinggi yang diteliti berdasarkan akumulasi dari parameter jumlah langkah, jumlah waktu, kelengkapan konten, dan kepuasan responden.

Dalam melakukan penilaian terhadap kepuasan responden pada saat dan setelah mengakses situs web Perguruan Tinggi, dilakukan beberapa hal berikut ini:

1. Pernyataan Mengenai Pendapat Setelah Mengakses Situs Web

2. Pertanyaan Mengenai Level Masalah Usability: Bagaimana pendapat Anda tentang masalah usability pada situs web ini?

Jawaban yang dapat dipilih oleh responden ada 5 (lima) poin, antara lain:

1) Tidak memiliki masalah usability sama sekali.

2) Masalah usability Ringan atau hanya masalah penampilan luar, sehingga masalah dapat diperbaiki hanya jika pengembang situs web memiliki waktu luang.

3) Masalah usability Sedang/Minor/Kurang Penting, sehingga perbaikan masalah hanya memerlukan prioritas yang rendah saja.

4) Masalah usability Berat/Mayor/Penting, sehingga penting untuk diperbaiki, sehingga memerlukan prioritas tinggi.

5) Masalah usability Sangat Berat, sehingga penting untuk diperbaiki sebelum situs web diluncurkan.

3. Penilaian Menggunakan Formulir QUIS (Questionnaire for User Interface Satisfaction)

\subsection{Parameter Penilaian Evaluasi Usability}

Parameter penilaian evaluasi usability yang digunakan pada penelitian ini antara lain:

\subsubsection{Parameter Jumlah Langkah}

Parameter ini diterapkan pada setiap skenario. Tahapan-tahapan yang dilaksanakan dalam menghitung parameter jumlah langkah, antara lain:

a) Video rekaman dibuka dan dijalankan pada perangkat lunak Camtasia versi 8.1.

b) Penghitungan langkah responden dalam mengakses situs web dimulai dari responden menatap halaman utama dan mencari informasi pada setiap skenario.

c) Hasil penghitungan langkah dimasukan ke dalam Microsoft untuk didokumentasikan, diolah dan dianalisis.

d) Dilakukan rekapitulasi dan penentuan ratarata jumlah langkah untuk setiap situs web, kemudian diurutkan dari yang paling sedikit hingga paling banyak langkahnya. Semakin sedikit rata-rata langkah yang diperoleh, maka situs web tersebut diduga semakin efisien dan efektif dalam hal usability.

\subsubsection{Parameter Jumlah Waktu}

Parameter ini diukur dalam satuan detik dan diterapkan pada setiap skenario. Tahapantahapan yang dilaksanakan dalam menghitung parameter jumlah waktu, antara lain:

a) Video rekaman dibuka dan dijalankan pada perangkat lunak Camtasia versi 8.1.

b) Penghitungan waktu responden dalam mengakses situs web dimulai dari responden menatap layar monitor dan pointer pada mouse bergerak mencari informasi pada masing-masing skenario.

c) Penghitungan waktu responden dihentikan pada saat responden tidak menatap ke arah layar monitor dan mouse berhenti mencari informasi.

d) Hasil dimasukan ke dalam Microsoft untuk didokumentasikan, diolah dan dianalisis.

e) Rekapitulasi dan penentuan rata-rata jumlah waktu untuk setiap situs web, kemudian diurutkan dari yang paling sedikit hingga 
paling banyak waktunya. Semakin sedikit rata-rata waktu yang dihasilkan, maka situs web tersebut diduga semakin efisien dan efektif dalam hal usability.

\subsubsection{Parameter Kelengkapan Konten}

Sebuah situs web dikatakan lengkap apabila informasi yang dicari telah berhasil ditampilkan di layar atau responden memberikan tanda cek pada kuesioner. Seluruh situs web diurutkan berdasarkan konten yang paling banyak ( 9 konten) hingga yang paling sedikit ( 6 konten), kemudian dinormalisasi dengan rentang yang baru menjadi 1-10.

\subsubsection{Parameter Kepuasan Responden} Questionnaire for User Interface Satisfaction (QUIS) digunakan untuk mengukur tingkat kepuasan responden pada penelitian ini. QUIS pertama kali diterbitkan oleh University of Maryland pada tahun 1988 (versi 1), sampai pada versi yang sekarang digunakan pada penelitian ini adalah versi 5.5 untuk mengukur kepuasan pengguna terhadap suatu sistem atau situs web. Kuesioner ini berisi 27 pertanyaan dengan skala jawaban dari $0-9$, namun yang digunakan pada penelitian ini hanya sebanyak 19 pertanyaan yang dianggap relevan dan tidak membingungkan bagi responden. Pertanyaan tersebut terbagi ke dalam beberapa bagian, yaitu pertanyaan mengenai reaksi keseluruhan terhadap situs web, halaman web, istilah dan informasi dalam situs web, serta kemampuan situs web.

Pada penelitian ini, setelah mengakses situs web dan menjawab pertanyaan mengenai pendapat, responden diberikan satu pertanyaan tambahan yang mengharuskan responden untuk menilai permasalahan usability dari situs web yang telah dievaluasi dengan cara memilih satu dari lima kondisi. Rata-rata skor kondisi permasalahan usability kemudian dikorelasikan dengan rata-rata skor QUIS untuk mengetahui apakah keduanya berhubungan atau tidak. Kelima kondisi permasalahan usability disesuaikan untuk mempermudah pemahaman responden dengan penyesuaian sebagai berikut:

1. Kondisi 1: Tidak memiliki masalah usability sama sekali. Untuk kondisi ini, skor yang diberikan adalah 5 .

2. Kondisi 2: Memiliki masalah usability tingkat ringan atau hanya masalah penampilan luar, sehingga masalah dapat diperbaiki hanya jika pengembang situs web memiliki waktu luang. Untuk kondisi ini, skor yang diberikan adalah 4 .

3. Kondisi 3: Memiliki masalah usability tingkat sedang/minor/kurang penting, sehingga perbaikan masalah hanya memerlukan prioritas yang rendah saja. Untuk kondisi ini, skor yang diberikan adalah 3.

4. Kondisi 4: Memiliki masalah usability tingkat berat/mayor/penting, sehingga penting untuk diperbaiki, sehingga memerlukan prioritas tinggi. Untuk kondisi ini, skor yang diberikan adalah 2.

5. Kondisi 5: Masalah usability sangat berat, sehingga penting untuk diperbaiki sebelum situs web diluncurkan. Untuk kondisi ini, skor yang diberikan adalah 1 .

\subsubsection{Skor Evaluasi Usability}

Evaluasi usability memiliki lima parameter penilaian, yaitu jumlah waktu, jumlah langkah, kelengkapan konten dan kepuasan responden. Hasil dari evaluasi usability adalah skor usability situs web Perguruan Tinggi berdasarkan parameter jumlah waktu, jumlah langkah, kesuksesan tugas, kelengkapan konten dan kepuasan responden yang telah dinormalisasi dengan Min-Max Normalization pada Persamaan (1) [13].

$v^{\prime}=\left(v-\min _{a}\right) /\left(\max _{a}-\min _{a}\right)$

Di mana:

v' = Data hasil normalisasi

$\mathrm{v} \quad=$ Data sebelum dinormalisasi

$\max _{\mathrm{a}} \quad=$ Nilai maksimum

$\min _{\mathrm{a}} \quad=$ Nilai minimum

\section{HASIL DAN PEMBAHASAN}

Responden yang menjalankan evaluasi usability adalah pelajar, mahasiswa dan masyarakat berjumlah 26 orang. Seluruh responden pada evaluasi usability dipilih dengan beberapa kriteria, yaitu mahir menggunakan komputer dan internet, terbiasa mencari informasi pada situs web, serta cukup sering menggunakan fasilitas e-mail untuk berkomunikasi. Sebanyak $31 \%$ responden 
berjenis kelamin perempuan dan $69 \%$ berjenis kelamin laki-laki. Responden yang berusia 17 25 tahun sebanyak $92 \%$ dan yang berusia $26-$ 35 tahun sebanyak $8 \%$. Keseluruhan responden memiliki jenjang pendidikan SMA/SMK sebanyak $19 \%$ dan sarjana (S1) sebanyak $81 \%$. Kondisi lingkungan pelaksanaan evaluasi usability dapat dilihat pada Gambar 1.

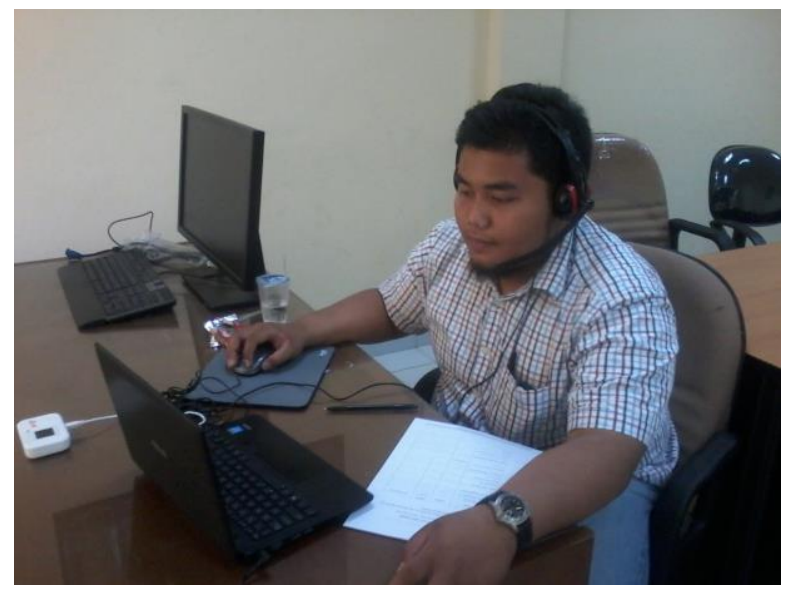

Gambar 1. Lingkungan pelaksanaan evaluasi usability.

\subsection{Parameter Jumlah Waktu dan Jumlah Langkah}

Parameter pertama yang menjadi acuan performa usability adalah parameter jumlah waktu diukur dalam satuan detik yang diperlukan oleh responden untuk melaksanakan tugas pada setiap skenario dimulai dari halaman mesin pencari untuk Skenario 1 dan halaman utama atau halaman pertama situs web untuk Skenario 2 sampai 9. Untuk kecepatan waktu untuk memuat informasi (loading time) diabaikan dikarenakan pemuatan informasi tergolong cepat menggunakan koneksi Internet yang telah disediakan.

Pada Gambar 2 didapatkan hasil bahwa situs web UGM memiliki rata-rata waktu terlama (494 detik), sedangkan situs web UNHAS memiliki rata-rata waktu tercepat (290 detik) dari ketujuh situs web yang diteliti. Hal ini diduga karena letak informasi yang ditampilkan oleh situs web UGM tergolong lebih sulit ditemukan karena memiliki menu utama di bagian atas dan menu pendukung di bagian paling atas serta di bawah menu utama. Sebaliknya letak informasi pada situs web UNHAS lebih mudah untuk ditemukan karena berfokus pada menu utama di bagian atas.

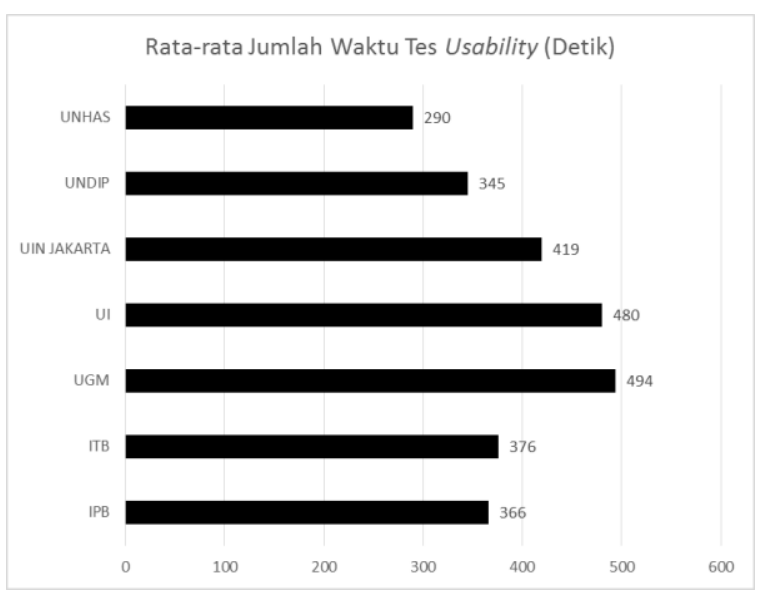

Gambar 2. Grafik rata-rata jumlah waktu tes usability

Pada penelitian ini faktor efisiensi lain yang dibahas ditentukan oleh faktor seberapa banyak langkah yang harus dilaksanakan oleh pengunjung untuk memperoleh informasi yang dibutuhkan dan disebut sebagai parameter jumlah langkah. Tindakan responden pada layar monitor komputer pada saat mengakses situs web yang dihitung sebagai langkah pada penelitian ini antara lain:

a. Menyorot menu, submenu atau tautan untuk mencari informasi,

b. Mengklik menu atau submenu untuk membuka halaman baru,

c. Menggulung (scroll) layar monitor ke atas atau ke bawah untuk mencari informasi,

d. Melakukan klik kanan untuk menyalin (copy) informasi atau melekatkan informasi (paste),

e. Mengetik karakter, kata atau kalimat dalam satu formulir atau kolom pengisian,

f. Membuka dan menutup tab atau window baru,

g. Menekan tombol Enter,

h. Mengklik tautan (link), tombol atau kolom pengisian

i. Mencari kata dengan menekan tombol Control bersamaan dengan tombol $\mathrm{F}$ pada keyboard (Ctrl-F)

j. Mengklik tombol kembali/back, dan

k. Melakukan reload/refresh halaman web dengan mengklik tombol reload atau menekan tombol F5. 
Grafik di bawah ini menampilkan perbandingan ketujuh situs web Perguruan Tinggi dalam hal jumlah langkah yang paling banyak dan paling sedikit untuk melaksanakan 9 skenario pada tes usability dari seluruh responden yang ada.

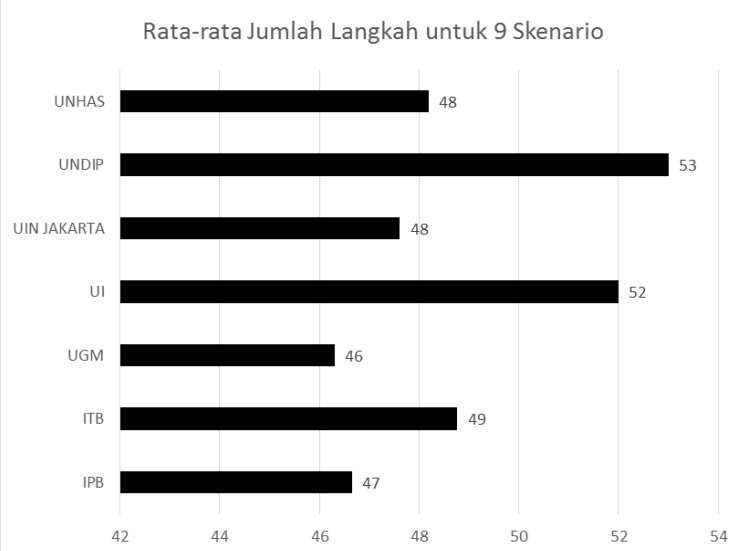

Gambar 3. Rata-rata jumlah langkah untuk 9 skenario tes usability

Pada grafik tersebut dapat dilihat bahwa situs web IPB yang memiliki jumlah langkah terbanyak (80 langkah) yang diperoleh dari salah satu respondennya untuk melaksanakan 9 skenario tersebut. Hal ini diduga karena responden kesulitan untuk mencari konten dikarenakan situs web IPB tidak memiliki fitur drop-down pada menunya dan memiliki cukup banyak tautan, sehingga responden melakukan langkah yang lebih banyak.

Adapun situs web UNHAS dan UIN Syarif Hidayatullah Jakarta memiliki jumlah langkah paling sedikit (21 langkah) yang dilakukan oleh salah satu respondennya untuk menjalankan kesembilan skenario. Hal ini diduga karena jumlah konten yang dimiliki oleh masing-masing situs web UIN Syarif Hidayatullah Jakarta dan UNHAS relatif sedikit, yakni 6 konten saja, sehingga responden tersebut dapat lebih cepat menyudahi pencarian terhadap konten yang diminta.

\subsection{Analisis Kepuasan Responden}

Hasil analisis kepuasan menurut responden menggunakan instumen QUIS dengan skala 0-9, antara lain:

- Tidak ada situs web Perguruan Tinggi yang memiliki Skor 5 (Kondisi 1) atau tidak memiliki permasalahan usability.
- Situs web Perguruan Tinggi yang memiliki Skor 4 (Kondisi 2) atau memiliki permasalahan usability tingkat ringan sebanyak 86\% (Enam Perguruan Tinggi).

- Tidak ada situs web Perguruan Tinggi yang memiliki Skor 3 (Kondisi 3) atau memiliki permasalahan usability tingkat sedang.

- Situs web Perguruan Tinggi yang memiliki Skor 2 (Kondisi 4) atau memiliki permasalahan usability tingkat berat sebanyak 14\% (Satu Perguruan Tinggi).

- Tidak ada situs web Perguruan Tinggi yang memiliki Skor 1 (Kondisi 5) atau memiliki permasalahan usability tingkat sangat berat.

Pada Gambar 4 terdapat informasi berupa rata-rata skor QUIS yang dirangkum dari seluruh responden. Rata-rata skor diperoleh dengan cara menjumlahkan rata-rata skor setiap pertanyaan yang dijawab oleh 26 orang responden pada masing-masing Perguruan Tinggi. Selanjutnya hasil penjumlahan rata-rata skor tersebut dibagi dengan angka yang diperoleh dengan mengurangkan jumlah pertanyaan QUIS (19 pertanyaan) dengan jumlah check list "Tidak Ada" yang dibubuhkan oleh responden pada kuesioner QUIS, sehingga pada akhirnya menghasilkan rata-rata skor. Berdasarkan grafik di bawah ini dapat dilihat bahwa Perguruan Tinggi UGM memperoleh skor tertinggi, yaitu 7.6, sedangkan skor terendah dimiliki oleh situs web UNDIP, yaitu 4.3.

\section{Modus Hasil QUIS 7 PTN}

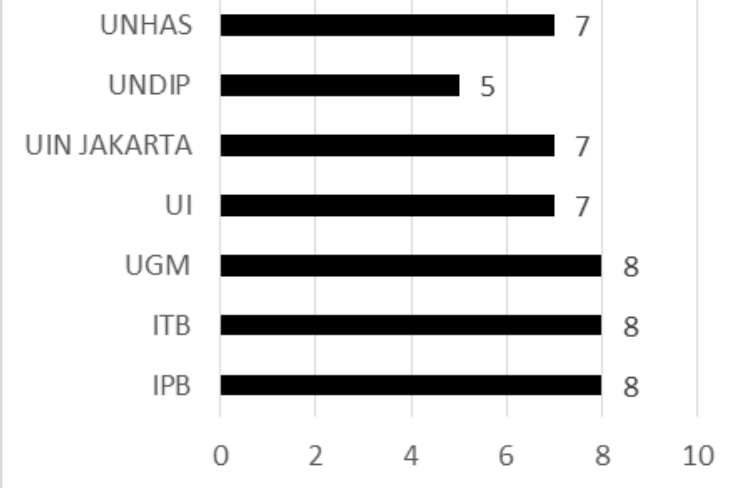

Gambar 4. Modus kepuasan responden terhadap 7 PTN dengan metode QUIS 
Hasil pengujian Korelasi Bivariat Spearman antara variabel rata-rata skor Questionnaire for User Interface Satisfaction dengan variabel rata-rata skor kondisi permasalahan usability adalah kuat, searah dan sangat nyata $(r=0.621, p=0.000)$ Adapun ambang batas untuk korelasi kuat yang digunakan adalah 0.5 - 1.00 [14]. Hal ini berarti apabila skor Questionnaire for User interface Satisfaction tergolong semakin tinggi, maka dapat diperkirakan bahwa skor kondisi permasalahan usability-nya juga akan semakin tergolong rendah (tidak ada permasalahan usability), dikarenakan sifat korelasinya cenderung kuat.

\subsection{Hasil Evaluasi Performa Usability}

Skor yang diperoleh pada evaluasi performa usability berasal dari penjumlahan skor parameter jumlah waktu, jumlah langkah, kelengkapan konten dan kepuasan pengguna. Keempat parameter tersebut sesuai dengan ISO 9241:11 yang menyatakan bahwa usability memiliki tiga komponen yaitu efisiensi, efektifitas dan kepuasan penggunaan. Parameter jumlah waktu dan jumlah langkah mewakili komponen efisiensi, parameter kelengkapan konten mewakili komponen efektivitas, sedangkan parameter kepuasan pengguna mewakili komponen kepuasan penggunaan. Situs web yang dapat digolongkan baik adalah situs web yang jumlah waktu dan langkahnya sedikit, namun memiliki konten yang lengkap dan kepuasan penggunaan yang tinggi.

Untuk memperoleh skor pada masingmasing parameter, dilakukan normalisasi data dengan memberikan skor 1-10 untuk menghindari hasil bernilai negatif seperti yang diperoleh jika menggunakan skor normalisasi 0 1. Proses normalisasi data tersebut diperlukan karena keempat parameter yang digunakan untuk menentukan skor evaluasi usability memiliki satuan dan rentang yang berbeda-beda. Parameter jumlah waktu memiliki satuan detik, parameter jumlah langkah memiliki satuan langkah, parameter kelengkapan konten memiliki satuan konten, dan parameter kepuasan pengguna memiliki satuan poin. Metode normalisasi data yang digunakan adalah metode Min-Max Normalization.

Penetapan skor performa usability pada penelitian ini menggunakan pendekatan skor terbalik, dimana skor terendah dimiliki oleh situs web yang terbaik menurut hasil evaluasi usability. Pada parameter jumlah langkah dan jumlah waktu, nilainya diurutkan dari Perguruan Tinggi yang memiliki nilai terkecil hingga terbesar. Kemudian nilai tersebut dinormalisasi dengan metode Min-Max Normalization untuk menyamakan rentang dengan parameter kelengkapan konten dan kepuasan pengguna, yaitu dari 1 sampai 10.

Adapun untuk parameter kelengkapan konten, nilainya berupa jumlah konten yang dimiliki situs web Perguruan Tinggi. Selanjutnya diberikan skor 0 sampai 1, dimana nilai terbesar diberi skor terkecil pula dikarenakan menyesuaikan dengan parameter jumlah langkah dan jumlah waktu. Adapun Perguruan Tinggi yang memiliki efektivitas tinggi dalam mencari informasi adalah Perguruan Tinggi yang memiliki jumlah langkah dan jumlah waktu yang sedikit atau rendah. Kemudian nilai tersebut dinormalisasi dengan metode Min-Max Normalization untuk menyamakan rentangnya dari 1 sampai 10 seperti pada parameter jumlah langkah dan jumlah waktu.

Untuk parameter kelengkapan konten, situs web diberi nilai berdasarkan jumlah informasi atau konten yang dimiliki dari 9 konten yang dicari pada evaluasi usability, sehingga nilai tertingginya adalah 9. Nilai tertinggi dimiliki oleh Perguruan Tinggi ITB dan UNHAS yang memiliki seluruh konten yang dijadikan sebagai skenario evaluasi. Hasil skor normalisasi dari seluruh parameter diakumulasi untuk menghasilkan skor yang disajikan pada Tabel 2 yang menampilkan skor akhir performa usability pada masing-masing situs web Perguruan Tinggi yang diurutkan dari skor terkecil (performa usability baik) hingga skor terbesar (performa usability kurang baik). 
Tabel 2. Skor evaluasi usability

\begin{tabular}{ccccccc}
\hline No. & Nama PTN & $\begin{array}{c}\text { Parameter } \\
\text { Kelengkapan } \\
\text { Konten }\end{array}$ & $\begin{array}{c}\text { Parameter } \\
\text { Jumlah } \\
\text { Langkah }\end{array}$ & $\begin{array}{c}\text { Parameter } \\
\text { Jumlah } \\
\text { Waktu }\end{array}$ & $\begin{array}{c}\text { Parameter } \\
\text { Kepuasan } \\
\text { Pengguna }\end{array}$ & $\begin{array}{c}\text { Total } \\
\text { Skor }\end{array}$ \\
\hline 1. & UNHAS & $\mathbf{1 , 0 0 1 8}$ & 3,8187 & $\mathbf{1 , 0 0 0 0}$ & 2,6495 & 5,8205 \\
2. & ITB & $\mathbf{1 , 0 0 1 8}$ & 4,5604 & 4,7992 & 2,8238 & 10,3614 \\
3. & IPB & 3,2500 & 1,8407 & 4,3377 & 3,5731 & 13,0014 \\
4. & UGM & 3,2500 & $\mathbf{1 , 3 9 5 6}$ & 9,9949 & $\mathbf{1 , 9 9 8 1}$ & 14,6405 \\
5. & UIN & 9,9946 & 3,0769 & 6,7064 & 3,0031 & 19,7780 \\
6. & UI & 3,2500 & 8,7143 & 9,3790 & 3,7746 & 21,3432 \\
7. & UNDIP & 9,9946 & 10,0000 & 3,4383 & 19,9963 & 23,4330 \\
\hline
\end{tabular}

Keterangan: Cetak Tebal $=$ Nilai terendah sebagai predikat tertinggi setiap kategori

Dari tabel di atas dapat dilihat bahwa situs web Perguruan Tinggi UNHAS merupakan situs web dengan performa usability tertinggi, sedangkan situs web Perguruan Tinggi UNDIP merupakan situs web dengan performa usability terendah. Situs web UNHAS memiliki skor usability tertinggi diduga karena konten yang dimilikinya lengkap (9 konten), konten-konten tersebut mudah ditemukan dengan langkah yang sedikit karena penempatan informasi pada situs web UNHAS cukup mudah untuk ditemukan karena terletak di menu utama yang terletak paling atas, serta kecepatan aksesnya cukup tinggi karena tidak memiliki gambar yang terlalu banyak. Adapun situs web UNDIP memiliki skor usability terendah diduga karena kontennya tidak lengkap (6 konten), konten yang ada sulit untuk dicari karena tidak memiliki menu bar hanya ditampilkan berbagai macam tautan (link) yang ada di bagian kanan dan kiri halaman situs web, dan kecepatan aksesnya tidak terlalu tinggi.

Apabila tujuan diadakannya penelitian, ternyata diketahui bahwa tidak semua situs web PTN terakreditasi A yang dievaluasi performa usability-nya sudah tergolong baik yang dinilai dari beberapa parameter seperti jumlah waktu akses, jumlah langkah, kelengkapan konten dan kepuasan pengguna, maka hipotesa tersebut terbukti. Hal ini berdasarkan hasil yang telah dikemukakan dimana masih terdapat situs web Perguruan Tinggi yang performa usability-nya perlu ditingkatkan seperti situs web dengan peringkat 5 sampai 7 di atas (UIN Syarif Hidayatullah Jakarta, UI dan UNDIP) karena tidak memiliki predikat paling baik seperti yang ditunjukkan dengan cetak tebal (bold) pada masing-masing kolom. Oleh karena itu, artikel ini juga menampilkan perubahan yang terjadi pada situs web UIN Syarif Hidayatullah Jakarta, UI dan UNDIP tahun 2017 setelah dilakukan uji performa usability pada tahun 2014.

Berdasarkan hasil rekomendasi yang dihasilkan sebagai saran dari hasil laporan penelitian ini dan penelitian sebelumnya [15], situs web UIN Syarif Hidayatullah Jakarta perlu meningkatkan kelengkapan kontennya dengan menambahkan fasilitas mesin pencari, buku tamu dan peluang kerja, selain itu perlu juga meningkatkan kecepatan waktu aksesnya. yakni melengkapi situs webnya dengan menu Saran berupa penggunaan mekanisme drop-down, fasilitas pencari informasi (Search), peta situs, dan breadcrumb navigation, sebagian telah diterapkan pada situs web UIN Jakarta pada situs web terbaruya. Sebagai contoh, seperti yang tampak pada Gambar 6, situs terbaru UIN Jakarta (Copyright tahun 2015) telah memiliki fasilitas Cari Informasi (Search) pada bagian pojok kanan atas Sebelumnya fasilitas ini tidak ada pada Gambar 5. Mekanisme drop-down (Gambar 6) juga telah disediakan oleh pengembang situs web, setelah sebelumnya tidak tersedia seperti pada laporan penelitian tahun 2014. 
Penyediaan fitur Breadcrumps (Gambar 7) tetap dipertahankan pada situs web UIN Jakarta. Untuk fasilitas berkomunikasi dengan pengunjung situs webnya, disediakan informasi alamat e-mail pada kolom "Kontak Kami", yaitu humas@uinjkt.ac.id. Hal ini diduga karena penggunaan $e$-mail sebagai media komunikasi sudah umum digunakan sehingga tidak membutuhkan fasilitas buku tamu secara terpisah.
Namun demikian, terdapat fasilitas yang sebelumnya ada tetapi tidak nampak pada situs web yang terbaru, yaitu Fitur Bahasa Arab seperti yang sebelumnya tampak pada Gambar 5 di bagian pojok kanan atas, sehingga hanya tersisa Bahasa Indonesia dan Bahasa Inggris saja. Adapun fitur yang masih belum dipenuhi oleh situs web UIN Jakarta adalah Peta Situs (Sitemap).

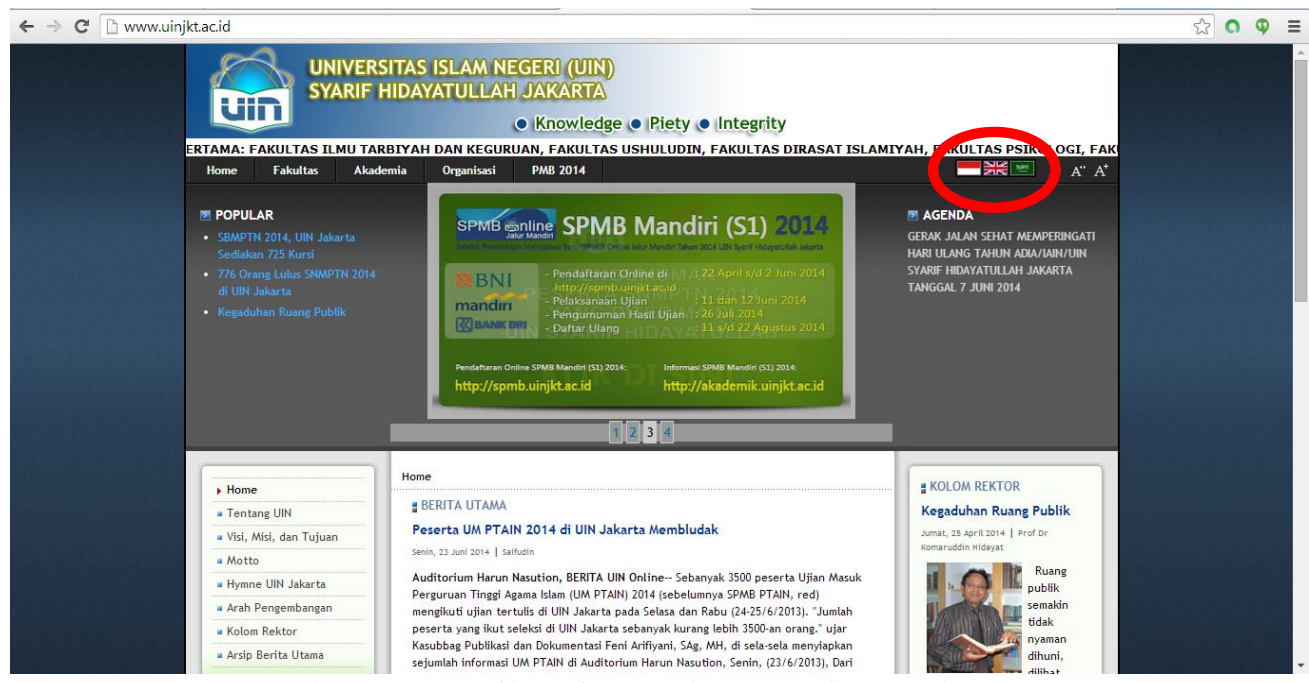

Gambar 5. Tampilan situs web UIN Jakarta tahun 2014

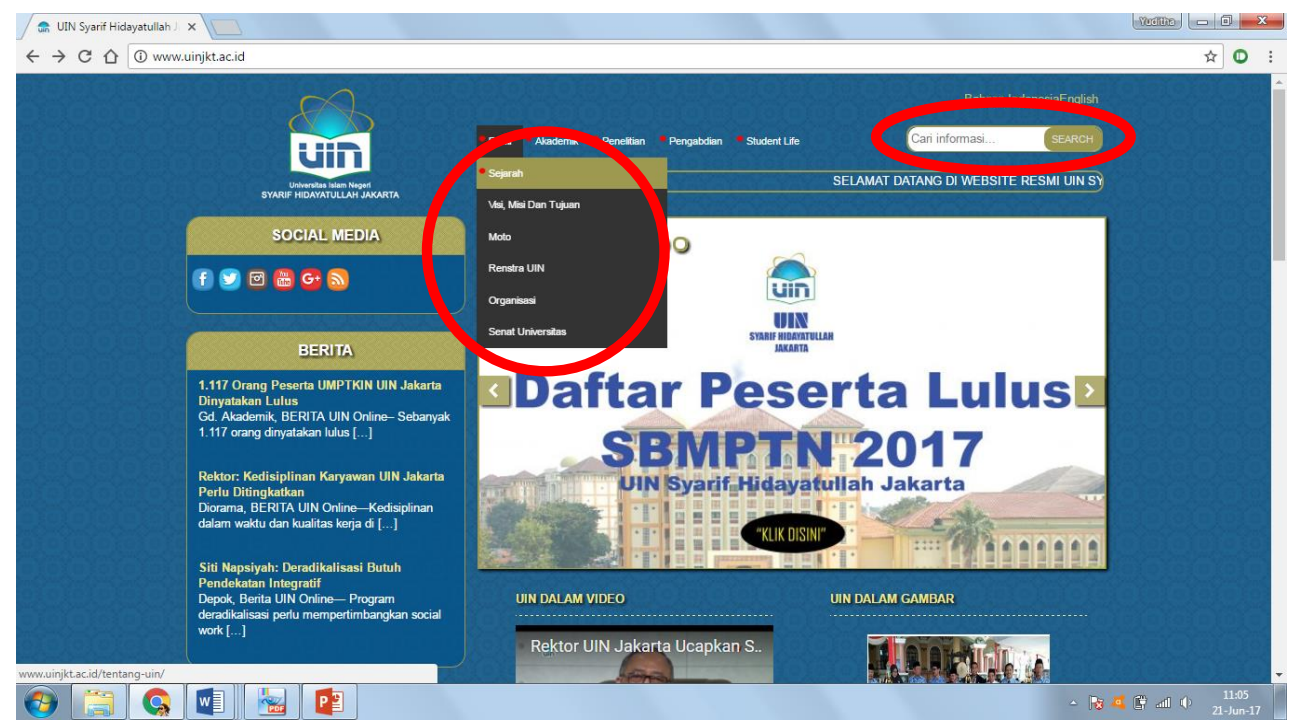

Gambar 6. Tampilan situs web UIN Jakarta tahun 2017 


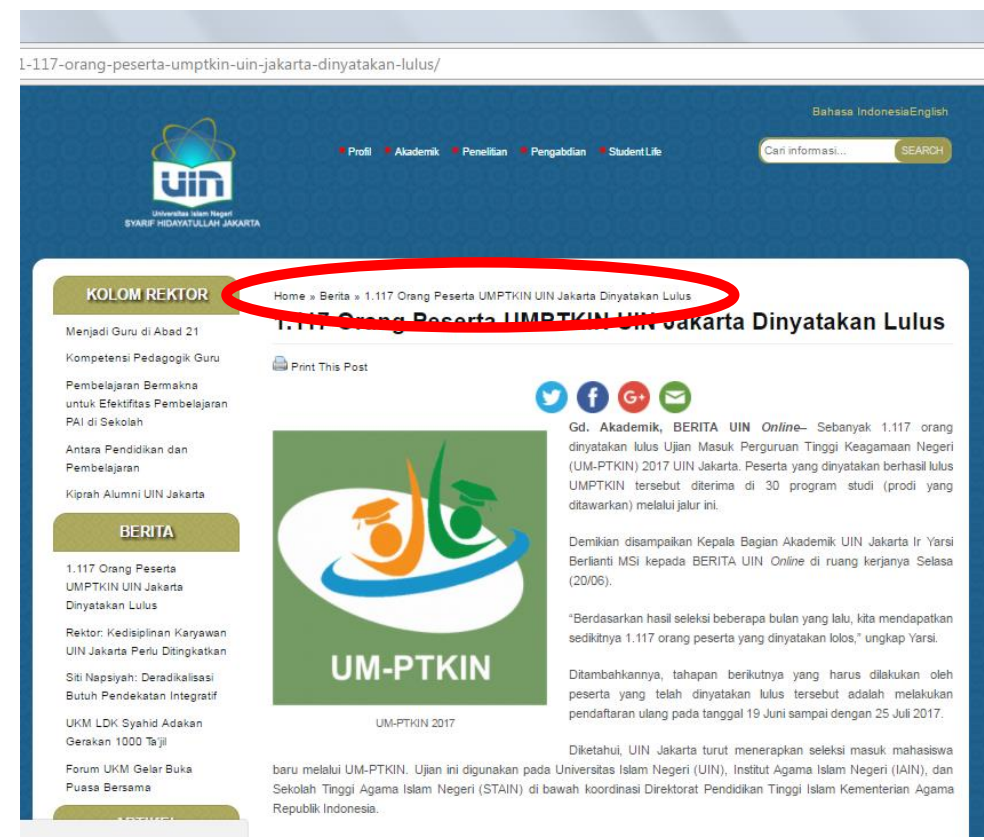

Gambar 7. Tampilan fitur breadcrumps (elips merah) situs web UIN Jakarta tahun 2017

Lain halnya dengan situs web UI yang telah disarankan perlu meningkatkan efektifitas langkah dan waktu dalam mengakses situs webnya, karena kedua parameter tersebut cukup besar menentukan performa usability. Pada Gambar 8 dan 9 dapat terlihat bahwa tidak ada perubahan yang signifikan dari segi tampilan situs web UI, namun ada penambahan menu bar utama dari berjumlah 5 menjadi 7 menu yang lebih spesifik dalam hal penamaannya, seperti menu Penelitian dan Inovasi, Penerimaan serta Mahasiswa.

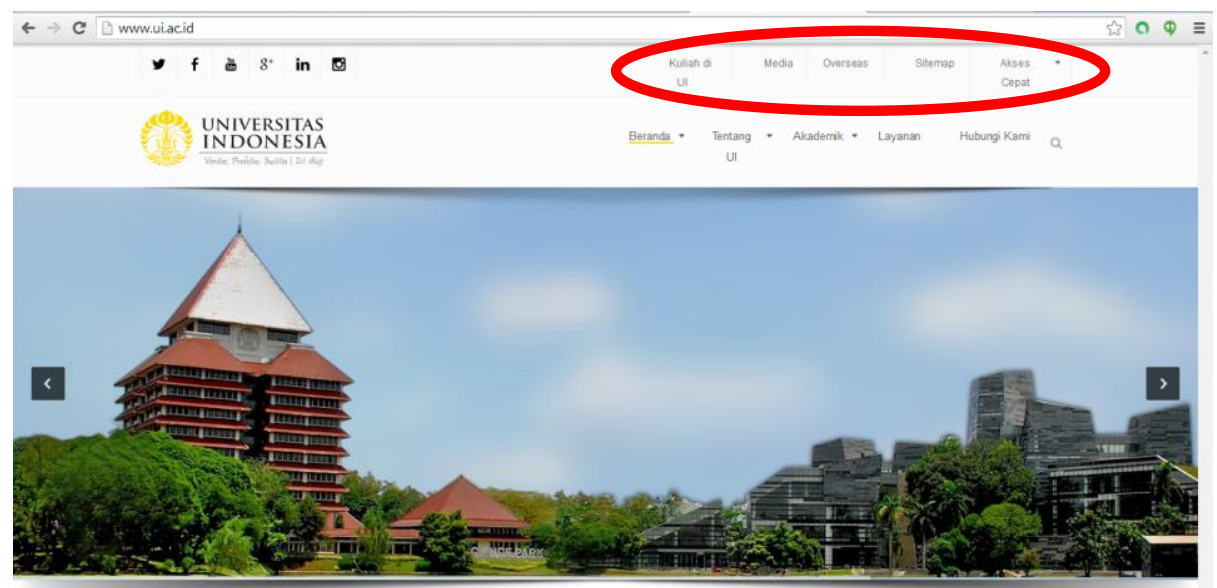

Gambar 8. Tampilan situs web UI tahun 2014 


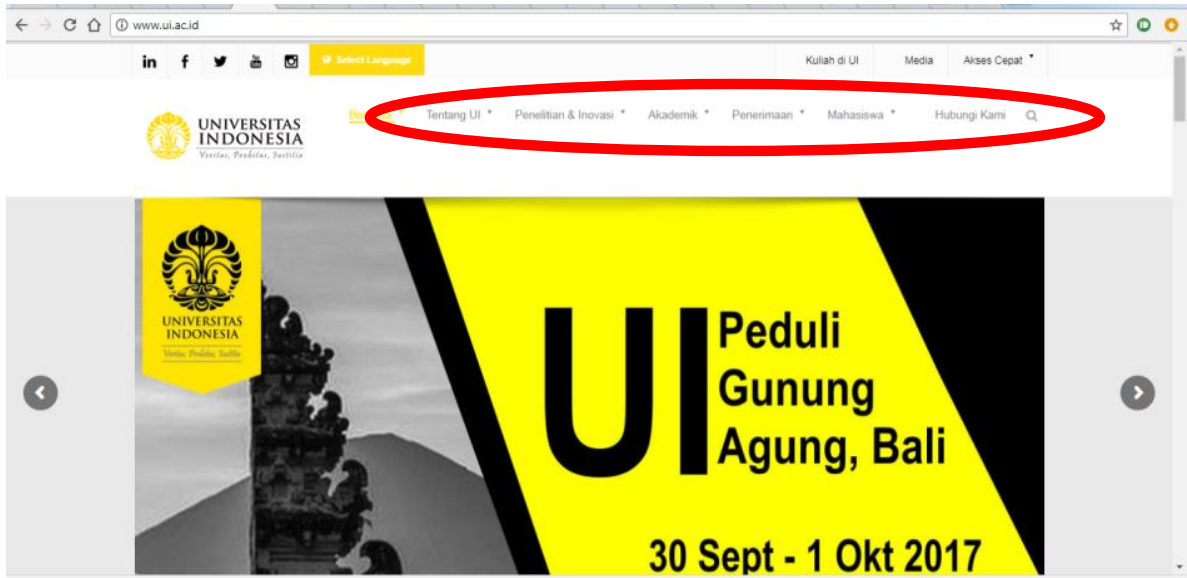

Gambar 9. Tampilan situs web UI tahun 2017

Adapun situs web UNDIP pada tahun 2014 (Gambar 10) perlu meningkatkan kelengkapan kontennya yaitu buku tamu, fasilitas mesin pencari dan peluang kerja. Selain itu, parameter jumlah langkah juga perlu diefektifkan dengan menambah menu bar dan mengurangi tautan ke situs web lain yang cukup memakan banyak langkah. Berdasarkan pada situs web terbaru UNDIP copyright tahun 2017 yang ditunjukkan pada Gambar 11, dapat dilihat situs web tersebut telah menggunakan menu bar di bagian atas (header) jika dibandingkan dengan Gambar 10 yang menggunakan sisi kiri sebagai area untuk meletakkan tautan (link).

Selain itu, pada Gambar 11 dapat dilihat bahwa fasilitas kontak telah dilengkapi dengan mencantumkan alamat surat elektronik dan tautan-tautan kepada media sosial UNDIP pada pojok kanan atas situs web. Hal ini akan memudahkan bagi pengunjung untuk berinteraksi dengan pengelola situs web dan diharapkan dapat meningkatkan kepuasan pengguna situs web.

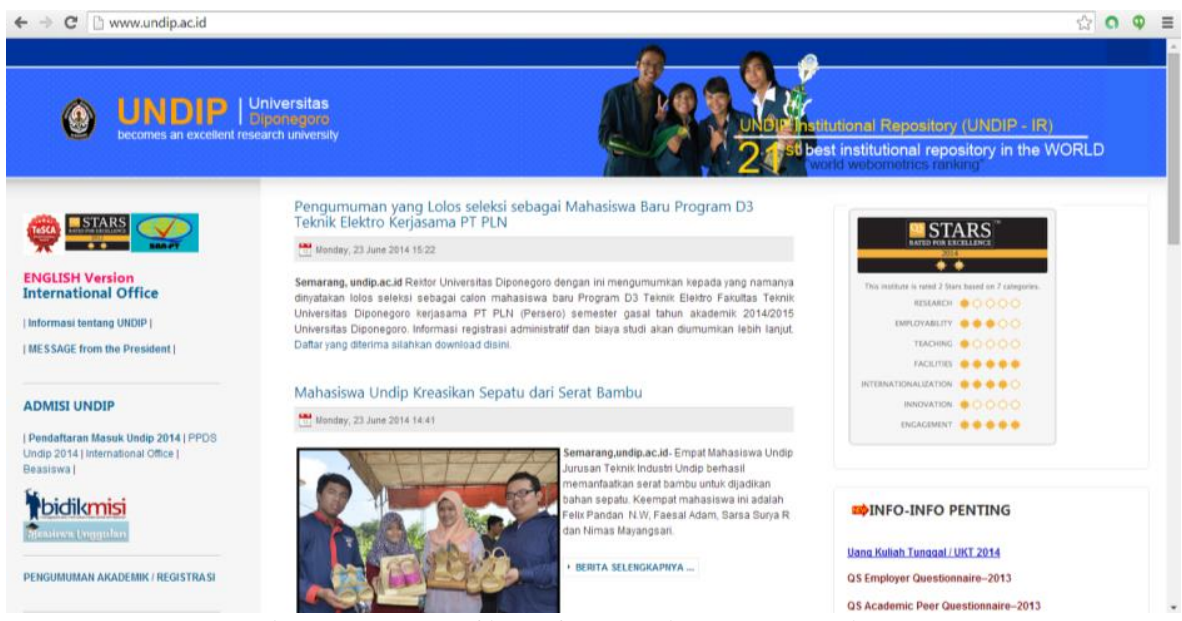

Gambar 10. Tampilan situs web UNDIP tahun 2014 


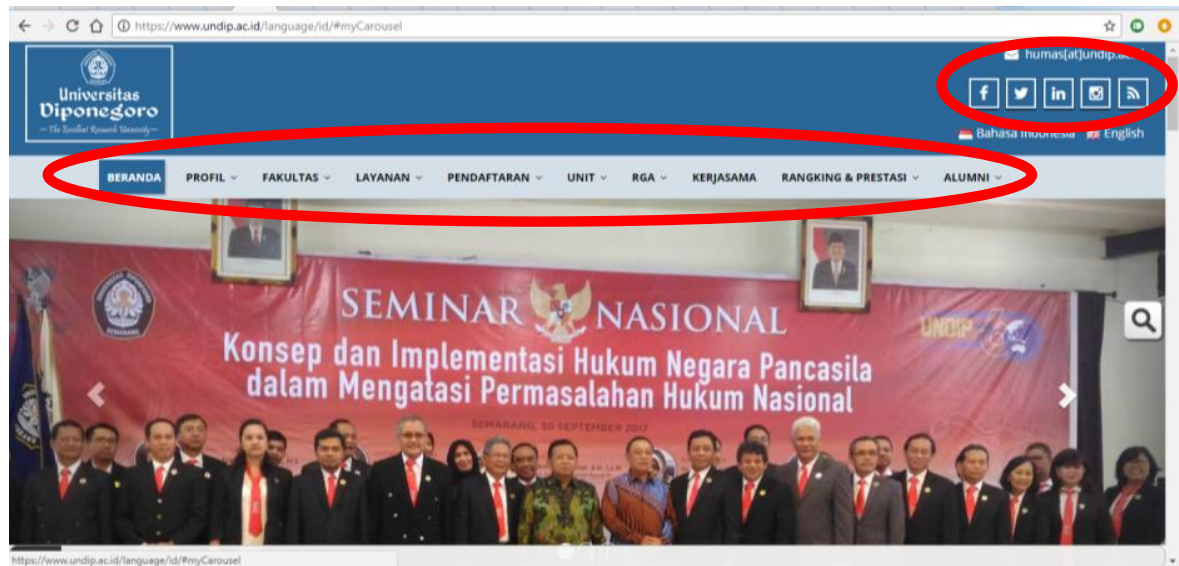

Gambar 11. Tampilan situs web UNDIP tahun 2017

\section{PENUTUP}

\subsection{Kesimpulan}

Penilaian hasil rekaman responden dalam hal performa usability situs web Perguruan Tinggi menggunakan empat parameter, yaitu jumlah waktu, jumlah langkah, kelengkapan konten dan kepuasan pengguna/responden. Penilaian kepuasan responden ditentukan oleh dua parameter, yaitu pertanyaan level masalah usability dan hasil formulir Questions of User Interface Satisfaction (QUIS). Perguruan Tinggi yang memperoleh skor kepuasan responden tertinggi dalam hal situs web adalah Universitas Gajah Mada. Adapun Perguruan Tinggi yang masih memiliki skor kepuasan responden terendah adalah Universitas Diponegoro.

Berdasarkan hasil uji korelasi antara hasil rata-rata QUIS dan rata-rata level permasalahan usability, dapat disimpulkan bahwa keduanya memiliki korelasi yang kuat, nyata dan searah $(r=0.621, p=0.000)$. Dengan kata lain, jika hasil rata-rata QUIS semakin tinggi, maka dapat diasumsikan kondisi permasalahan usability situs web tersebut akan semakin rendah levelnya sampai pada tahap tidak ada masalah usability.

Situs web Perguruan Tinggi UNHAS memiliki performa usability tertinggi dengan skor terkecil berdasarkan hasil normalisasi, yaitu 5.8205, sedangkan situs web Perguruan Tinggi UNDIP memiliki performa usability terendah dengan skor terbesar, yaitu 23.4430. Situs web yang telah meningkatkan performa usability dapat ditingkatkan dengan menambah beberapa fitur dan fasilitas seperti menu yang menggunakan mekanisme drop-down adalah situs web UI, ITB, UGM, UNHAS, dan UIN Syarif Hidayatullah Jakarta; memperpendek jarak scrolling-down, yaitu situs web UGM dan ITB; menambah fasilitas pencari informasi, yakni situs web ITB, IPB, UI, UGM, dan UNHAS; peta situs, yaitu situs web ITB dan UI; dan breadcrumb navigation yaitu situs web UI, IPB dan UIN Syarif Hidayatullah Jakarta.

Berdasarkan hasil pengamatan situs web UIN Jakarta terbaru tahun 2017, diperoleh hasil bahwa terdapat perbedaan dalam hal penambahan fasilitas mesin pencari dan mekanisme drop-down pada bagian menu. Namun demikian, setelah diobservasi ternyata ada pula fasilitas yang dihilangkan pada situs web tersebut, yaitu Bahasa Arab, sehingga kini hanya tinggal Bahasa Indonesia dan Bahasa Inggris saja.

Sementara pada situs web UI tahun 2017 telah ditambahkan 7 menu bar dari yang semula hanya 5 menu bar di tahun 2014, dimana penambahan tersebut adalah perpidahan dari sub-header di bagian paling atas. Adapun pada situs web UNDIP telah menggunakan menu bar di bagian atas (header) setelah sebelumnyta hanya menggunakan tautan dan ditambahkan pula alamat surat elektronik dan tautan-tautan kepada media sosial UNDIP sehingga dapat meningkatkan komunikasi pengelola situs web dengan para pengunjung. 


\subsection{Saran}

Hal-hal yang dapat disarankan berdasarkan hasil penelitian ini yaitu evaluasi usability dapat dilakukan secara berkala oleh institusi yang bersangkutan disertai dengan evaluasi kepuasan pengguna misalkan dalam kurun waktu 5 (lima) tahun sekali. Berdasarkan hasil evaluasi tersebut, pihak pengelola situs web dapat memperbaiki performa situs web tersebut dengan lebih terarah, efektif dan efisien karena memperoleh masukan dari end-users yang menjadi responden secara langsung.

Responden yang terlibat dapat terdiri dari mahasiswa, dosen, staf, calon mahasiswa yang berasal dari latar belakang yang berbedabeda, yaitu dari segi asal sekolah (SMA, SMK, Pesantren, Madrasah Aliyah, dan lain-lain yang sederajat). Selain itu, responden juga bisa berasal dari kalangan akademisi, seperti dosen dan mahasiswa pascasarjana yang membutuhkan informasi publikasi (jurnal, prosiding, artikel dan lain-lain) dari Perguruan Tinggi yang bersangkutan.

\section{DAFTAR PUSTAKA}

[1] Krug, S. 2010. Rocket Surgery Made Easy: The Do-It-Yourself Guide to Findingand Fixing Usability Problems. California: New Riders.

[2] Schumacher, RM, Lowry, SZ. 2010. NISTIR 7741: NIST Guide to the Processes Approach for Improving the Usability of Electronic Health Records. National Institute of Standards and Technology and U.S. Department of Commerce

[3] Almind TC, Ingwersen P. Informetric Analyses on the World Wide Web: Methodological Approaches to 'Webometrics'. Journal of Documentation, Vol 53, No. 4, September 1997.

[4] [BAN PT] Badan Akreditasi Nasional Perguruan Tinggi. 2017. Direktori Hasil Akreditasi Institusi. https://banpt.or.id/direktori/institusi/penca rian_institusi
[5] Mayhew DJ. 1999. The Usability Engineering Life Cycle. San Francisco: Morgan Kauffman

[6] Tullis T, Albert B. 2008. Measuring User Experience Collecting, Analyzing, and Presenting Usability Metrics Interactive Technologies. Massachusetts: Morgan Kauffman.

[7] Nielsen J. 1993. Usability Engineering. San Francisco: Morgan Kaufmann.

[8] Rekarti E. 2011. Kualitas dan Fitur Website Kampus dalam Mempengaruhi Kepuasan Mahasiswa Pengguna. JE/9/JULI/2011.

http://portal.kopertis3.or.id/bitstream/123 456789/1090/1/KUALITAS\%20DAN\%2 0FITUR\%20WEBSITE\%20KAMPUS\%2 ODALAM\%20MEMPENGARUHI\%20K EPUASAN\%20MAHASISWA\%20PENG GUNA.pdf

[9] DeLone WH, McLean ER. 2003. The DeLone and McLean Model of Information System Success: A Ten-Year Update. Journal of Management Information Systems, Vol 19(4), pp 9 30.

[10] Rubin J., Chisnell D. 2008. Handbook of Usability Testing, Second Edition: How to Plan, Design, and Conduct Effective Tests. Indianapolis: Wiley Publishing Inc.

[11] ComLabs. 2011. Pengembangan Website Perguruan Tinggi Standar Webometrics. http://training.comlabs.itb.ac.id/

[12] Singh, IK. 2003. Criteria for the development of effective university web sites. South African Journal of Information Management. Vol 5(3) September 2003.

[13] Al Shahabi L, Shaaban Z, Kasasbeh B. 2006. Data mining: a preprocessing engine. Journal of Computer Science 2(9):735-739.

http://oaj.unsri.ac.id/files/scipub/jcs29735 -739.pdf.

[14] Santoso, S. 2010. Statistik Parametrik: Konsep dan Aplikasi dengan SPSS. Jakarta: Elex Media Komputindo.

[15] Ichsani Y. 2012. Pengembangan Framework untuk Mengukur Usability dan Accessibility pada Situs-situs Web E- 
Government Provinsi di Indonesia. Tesis Program Pascasarjana. Bogor: Sekolah Pascasarjana Institut Pertanian Bogor.

\section{Ucapan Terima Kasih}

Peneliti mengucapkan terima kasih atas terselenggaranya penelitian ini dengan menggunakan dana dari hibah penelitian LEMLIT (Lembaga Penelitian) UIN Syarif Hidayatullah Jakarta tahun 2014. 